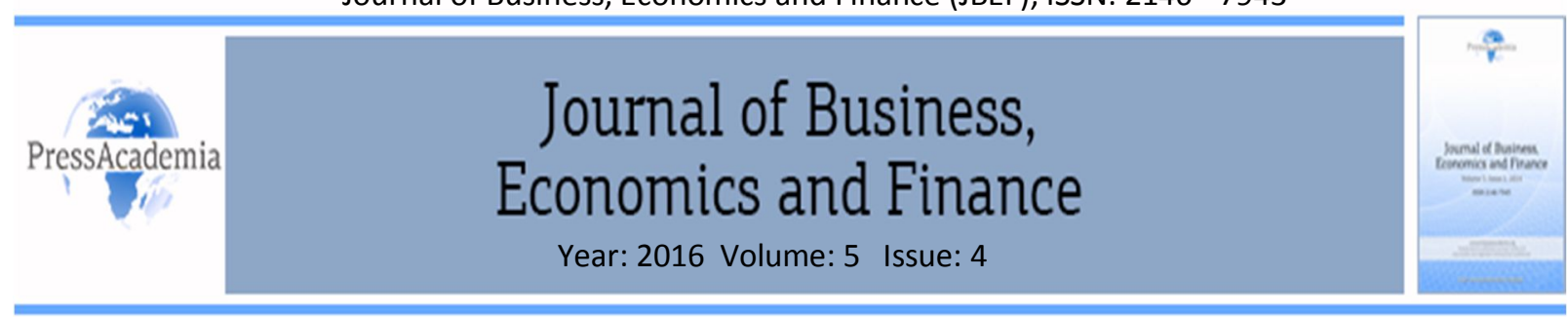

\title{
GARDEN OF MENTORING: REVISITING MENTORING IN ENTREPRENEURIAL SENSE
}

\section{DOI: 10.17261/Pressacademia.2017.359}

\author{
Seray Begum Samur Teraman ${ }^{1}$, Hande Sinem Ergun ${ }^{2}$ \\ ${ }^{1}$ Marmara University, begum samur@yahoo.com \\ ${ }^{2}$ Marmara University, sergun@marmara.edu.tr
}

\begin{abstract}
For many years, mentoring has been used as the influential career development tool in organizations. From a wider perspective, mentoring is perceived as a way of people development by helping individuals to achieve something meaningful in their lives. However, due to proliferation of entrepreneurial initiatives, now it is not only scrutinized from an intra-organizational perspective, but also it is considered a tool for self-employed development. Therefore, new area for cultivation in the garden of mentoring has emerged: Entrepreneurial Mentoring. Although, its multi-faceted development effect for new ventures is accepted, mentoring is not highly discussed topic in entrepreneurship literature to the best of our knowledge (St-Jean and Mathieu, 2015, St-Jean and Audet,2009). Hence, this conceptual study mainly deals with definitional issues, roots of mentoring and how mentoring evolves from career development towards entrepreneurial development perspective. The concern is offering some insights about multiple roles of mentoring, especially for new-start ventures as a supportive mechanism in their entrepreneurial journey.
\end{abstract}

Keywords: Mentoring, entrepreneurial mentoring, entrepreneurship, new-start ventures, career development. JEL Classification: L26, M13, M12

\section{INTRODUCTION}

In general sense mentoring is a tool contributing to adult development and career growth (Kram, 1985). In entrepreneurship literature, it is also used as a process of matching a new-start entrepreneurs (Sullivan, 2000) with an experienced person who have either started a new venture or worked as a professional in several initiatives/companies, provides advice and assistance to avoid costly and fatal mistakes in entrepreneurial ventures (St-Jean and Mathieu, 2015; St-Jean and Audet, 2009; Sullivian, 2000). As a practice, mentoring allows new-start entrepreneurs or mentee/protégé to make informed choices and persevere when faced with difficulties. They are also skilled at resolving personal and professional dilemmas by provoking self-questioning (St-Jean and Mathieu,2015). Despite their important functions in entrepreneurial process, their multi-faceted development effect for new-start entrepreneurs or mentee/protégé is not highly discussed topic in the entrepreneurship literature to the best of our knowledge (St-Jean and Mathieu, 2015; St-Jean and Audet,2009). However, mentoring programs provided under both several private and public initiatives are increasingly on the agenda of fostering entrepreneurship. As key strategic partners, universities, governments, and other industry participants have initiated several programs in which mentoring programs with different characteristics provided to new-start entrepreneurs (Easley and Wang, 2014). Proliferation of pre-incubation, incubation, acceleration programs, government sponsored Small and Medium Sized (SMEs) entrepreneurship education agendas and other private education efforts show that entrepreneurial efforts are supported to some degree under some structured initiatives around the world which feature mentorship components (Bruneel, Ratinho, Clarysse and Groen, 2012; Eesley and Wang, 2014). Therefore, ultimate aim of this conceptual study is to explore the garden of mentoring and to find out entrepreneurial mentoring as a way of developing entrepreneurship. Firstly, roots and evolution of mentoring has been briefly discussed. Mentoring is further elaborated with definitions drawn from mainstream mentoring literature. Then, mentoring construct has been expanded to entrepreneurship literature. Lastly, the importance of mentoring for new-start ventures as a supportive mechanism has been brought forward for future studies. 


\section{REVIEW OF MENTORING LITERATURE}

\subsection{Garden of Mentoring: Brief Discussion about Definitional Issues, Roots, and Evolution of Mentoring}

As stated garden metaphor in Kram and Ragin's (2007) Handbook of Mentoring, we do have more topics to be discussed in mentoring literature, more areas are waiting to be cultivated. It has been almost 30 years, scholars have been dealing with mentoring. Since then, these efforts have spread around several disciplines. Scholarly research has provided us to delve into the construct of mentoring in terms of definitional issues, relationship dynamics in organizational settings and outside of organizations, types of mentoring programs provided, mentoring relationship arisen naturally other than organized programs so on so forth. Although there has been a great deal of research in this field, it is argued that mentoring literature is still very young, seems to be a child in primary school. Thus, from several aspects this field needs to be developed (Ragins and Kram,2007; Wanberg et al 2003).

In general sense, mentoring is defined as an approach for people development by helping to achieve something important in the life (Kay and Hinds, 2009). This achievement could be about both an educational and professional life or any other spheres of life. In all segments for development, people need training and getting instructions given by more experienced people (Kay and Hinds, 2009). As stated by Kay and Hinds' mentoring schemes, this could be in the form of formal periods of training, preparation for vocational or professional qualifications, introduction of new employees into new jobs, helping members of staff for medium and long term development aspirations, preparing senior members to the next level posts, developing processes for staff of some higher educational institutions, developing gifted pupils, those with particular learning needs and helping those individuals to develop required skills in social activities (Kay and Hinds, 2009). It is about helping people to make their own choices, thus it is not dictating what to do or how to do (Kay and Hinds,2009:5). It is a form of practice that makes people questioning what, how, why, when and with whom they are doing, therefore allow people to make informed choices and persevere when faced with difficulties (St-Jean and Mathieu, 2015). As the important training and development tool for upward progression, mentoring is not a new concept (Hunt and Micheal,1983). This ancient archetype (Ragins and Kram, 2007) dates to Homer's Odyssey in that Ulysses entrusts his son Telemachus to his good friend called Mentor before leaving for the siege of Troy. For ten years, this mythical wise and faithful advisor Mentor was to be responsible for Telemachus' education and the development of his identity in the adult world. He acted faithfully as teacher, adviser, friend, and surrogate father to Telemachus. The goddess Athena spoke to Telemachus through Mentor, with the result that he acquired divine qualities and became the incarnation of wisdom. This also explains ancient Greek tradition of pairing young male citizens with older males to provide each boy to learn and emulate values of the Mentor. Likely, in ancient times young boys were traditionally apprenticed to a master who own a shop or business to learn details of trade (Bishop, 2012; Hunt and Micheal,1983; Murray, 2001; St-Jean and Audet, 2009). His master goes with him along this learning journey until the new master would take over the business at the old one's retirement or death. From ancient times to industrial societies, this master-apprentice relationship was transformed a new form of structured relationship between employeremployee (Murray, 2001). Therefore, this archetype offers insights into mentoring relationship exceeding time, gender, and culture. While it is explained through myths, it is a very real and social relationship for years, even it has been reshaped in several contexts (Ragins and Kram, 2007). As in ancient times, today in the technology driven twenty-first century, people need mentoring to have skills for mastering more complex issues and tasks in every working environment (Murray, 2001)

Levinson's seminal work of The Seasons of a Man's Life has been used for the basis of scholarly interest in role of mentoring in human development. In that study providing chronology of the lives of 40 men transitions in their lives, mentor is described as a guide, teacher, counsellor, and developer of skills facilitating the realization of their dreams. Levinson is said to go on to discuss the influential role of a mentor by stating that not having a mentor or having a poor mentor is the equivalent of poor parenting in childhood (Levinson, 1978 cited in Eby, Rhodes and Allen, 2007; Ragins and Kram,2007). Kram's work of Mentoring at Work conducted in 1985 is another ground-breaking study which delineates the key aspects of mentoring relationship including functions, phases, and complexities (Eby et al 2007; Ragins and Kram,2007). This study delineates the key aspects of mentoring relationship including functions, phases, and complexities (Eby et al 2007; Ragins and Kram,2007). Based on stated scholarly efforts, there are several definitions made in the literature considering mentoring. Principally, it has been defined as "the relationship between an older, more experienced mentor and 
a younger, less experienced protégé for the purpose of helping and developing the protégé's career" (Ragins and Kram, 2007). Illustrative definitions considering mentor, mentoring and mentorship from the literature are also shown in the Table 1 below.

Table 1: Illustrative Definitions on "Mentor, Mentoring, Mentorship" in the Literature

\begin{tabular}{|c|c|}
\hline AUTHOR (S) & DEFINITION \\
\hline David Marshall Hunt and Carol Michael & $\begin{array}{l}\text { Mentorship is an important training and development tool for } \\
\text { upward professional progression in organizations. Mentorship is the } \\
\text { development process in many occupations: master-apprentice; } \\
\text { physician-intern; and teacher and student (1983: 475). }\end{array}$ \\
\hline Kathy E. Kram and Lynn A. Isabella & $\begin{array}{l}\text { Mentors provide young adults with career enhancing functions such } \\
\text { as sponsorship, coaching, facilitating exposure and visibility, and } \\
\text { offering challenging work or protection, all of which help the younger } \\
\text { person to establish role in the organization, learn the ropes and } \\
\text { prepare for advancement (1985:111). }\end{array}$ \\
\hline Raymond A. Noe & $\begin{array}{l}\text { The mentor is usually a senior, experienced employee who serves as } \\
\text { a role model, provides support, direction, and feedback to the } \\
\text { younger employee regarding career plans and interpersonal } \\
\text { development, and increases the visibility of the protégé to decision- } \\
\text { makers in the organization who may influence career opportunities } \\
(1988: 148) \text {. }\end{array}$ \\
\hline Ellen A. Fagenson & $\begin{array}{l}\text { In general, mentoring is considered to be a development relationship } \\
\text { that enhances both an individual growth and advancement (1989: } \\
309 \text { cited Kram,1985). }\end{array}$ \\
\hline Belle Rose Ragins and John L. Cotton & $\begin{array}{l}\text { A mentor can generally be defined as a high-ranking, influential } \\
\text { member of your organization who has advanced experience and } \\
\text { knowledge and who is committed to providing upward mobility and } \\
\text { support to your career." (1993:101). }\end{array}$ \\
\hline William T. Whitely and Pol Coetsier & $\begin{array}{l}\text { Mentoring is a particular kind of interpersonal relationship that can } \\
\text { influence career progress and personal well-being (1993:421). }\end{array}$ \\
\hline $\begin{array}{l}\text { Terri A. Scandura and Chester A. } \\
\text { Schriesheim }\end{array}$ & $\begin{array}{l}\text { Supervisory mentoring is a transformational activity involving a } \\
\text { mutual commitment by mentor and protégé to the latter's long-term } \\
\text { development, as a personal, extra-organizational investment in the } \\
\text { protégé by the mentor, and as the changing of the protégé by the } \\
\text { mentor, accomplished by the sharing of values, knowledge, } \\
\text { experience and so-forth (1994:1589 cited from Hunt and } \\
\text { Micheal,1983 and Kram, 1985). }\end{array}$ \\
\hline Ellen J. Mullen & $\begin{array}{l}\text { A mentoring relationship is a one to one relationship between a more } \\
\text { experienced member (mentor) and a less experienced member } \\
\text { (protégé) of the organization or profession. The relationship is } \\
\text { developed to promote the professional and personal growth of the } \\
\text { protégé through coaching, support and guidance. Through } \\
\text { individualized attention, the mentor transfers needed information, } \\
\text { feedback and encouragement to the protégé as well as providing } \\
\text { emotional support and putting in a good word when possible } \\
(1994: 259) \text {. }\end{array}$ \\
\hline $\begin{array}{l}\text { Daniel B. Turban and Thomas W. } \\
\text { Dougherty }\end{array}$ & $\begin{array}{l}\text { Mentoring is a set of role activities, including coaching, support, and } \\
\text { sponsorship that upper level managers provide to protégés } \\
(1994: 688) \text {. }\end{array}$ \\
\hline
\end{tabular}




\begin{tabular}{|c|c|}
\hline Benneth J. Tepper & $\begin{array}{l}\text { Mentoring relationships facilitate junior colleagues' (protégés) } \\
\text { professional development and career progress (1995:1191). }\end{array}$ \\
\hline $\begin{array}{l}\text { Stacy, E. McManus and Joyce E.A } \\
\text { Russell }\end{array}$ & $\begin{array}{l}\text { Mentoring is a developmental relationship typically occurring } \\
\text { between senior and junior individuals in organizations (1997:145 } \\
\text { (cited Kram's } 1985 \text { work). }\end{array}$ \\
\hline Lillian T. Eby & $\begin{array}{l}\text { Mentoring is one mechanism by which individuals may be able to } \\
\text { develop skills and competencies that will help them adapt to } \\
\text { organizational changes in the workplace. Mentoring is typically } \\
\text { defined as a relationship between a senior organizational member } \\
\text { (the mentor) and a junior member of the organization (the protégé') } \\
\text { that is designed to help the protégé advance within the organization } \\
\text { (1997: } 126 \text { cited Kram, 1985). }\end{array}$ \\
\hline Tammy D. Allen and Mark L. Poteet & $\begin{array}{l}\text { Mentoring reflects a relationship between two individuals, usually a } \\
\text { senior and junior employee, whereby senior employee takes the } \\
\text { junior employee "under his or her wing" to teach the junior } \\
\text { employee about his or her job, introduce the junior employee to } \\
\text { contacts, orient the employee to the industry and organization and } \\
\text { address social and personal issues that may arise on the job (1999:59 } \\
\text { cited Kram's } 1985 \text { work). }\end{array}$ \\
\hline $\begin{array}{l}\text { Angela M. Young and Pamela L. } \\
\text { Perrewe }\end{array}$ & $\begin{array}{l}\text { Mentoring has been thought of as a relationship between a very } \\
\text { experienced senior person and a novice (2000:613). }\end{array}$ \\
\hline Margo Murray & $\begin{array}{l}\text { Mentoring is a deliberate pairing of a more skilled or more } \\
\text { experienced person with a less skilled or less experienced one, with } \\
\text { the mutually agreed goal of having the less skilled person grow and } \\
\text { develop specific competencies ( } 2001 \text { from preface). }\end{array}$ \\
\hline $\begin{array}{l}\text { Steven J. Armstrong, Christoper W. } \\
\text { Allinson and John Hayes }\end{array}$ & $\begin{array}{l}\text { Mentoring process is defined as a developmental, caring, sharing, } \\
\text { helping relationship where one person invests time, know-how and } \\
\text { effort in increasing and improving another person's growth, } \\
\text { knowledge and skills (2002:1112 cited Shea,1995) }\end{array}$ \\
\hline Burleson, MacGeorge, Knapp and Daly & $\begin{array}{l}\text { Mentoring is a dyadic "communication relationship" consisting of } \\
\text { verbal and nonverbal behaviours intended to offer or ask for help } \\
\text { (2002 cited from Memon et al 2015:2). }\end{array}$ \\
\hline Ensher, Grant-Vallone and Marelich & $\begin{array}{l}\text { Traditionally, a mentor has been defined as someone senior in age } \\
\text { and experience, and who provides guidance and upward mobility to } \\
\text { his or her protégés. A mentor can be defined as an individual with } \\
\text { greater or equal career experience than his or her protégé and who } \\
\text { can provide vocational, psychosocial, or role-modelling support } \\
\text { (2002:1407 cited Hunt and Michael, 1983; Ragins, 1989). }\end{array}$ \\
\hline W. Brad Johnson & $\begin{array}{l}\text { Mentoring is a personal relationship in which a more experienced } \\
\text { (usually older) faculty member or professional acts as a guide, role } \\
\text { model, teacher, and sponsor of a less experienced (usually younger) } \\
\text { graduate student or junior professional. A mentor provides the } \\
\text { protégé with knowledge, advice, challenge, counsel, and support in } \\
\text { the protégé 's pursuit of becoming a full member of a particular } \\
\text { profession (2002:88 cited Clark et al., 2000; Johnson, Koch, Fallow, } \\
\text { and Huwe, 2000). }\end{array}$ \\
\hline $\begin{array}{l}\text { Val Singh, Divindra Bains and Susan } \\
\text { Vinnicombe }\end{array}$ & $\begin{array}{l}\text { Mentors are those individuals with advanced experience and } \\
\text { knowledge who are committed to providing upward support and } \\
\text { mobility to their protégé's careers' (2002:391). }\end{array}$ \\
\hline
\end{tabular}




\begin{tabular}{|c|c|}
\hline $\begin{array}{l}\text { Lea Waters, Marita McCabe, Dennis } \\
\text { Kiellerup and Steven Kiellerup }\end{array}$ & $\begin{array}{l}\text { Mentoring has been described as a one-to-one relationship between } \\
\text { an experienced person (a mentor) and a less experienced person } \\
\text { (protégé) that provides a variety of developmental functions } \\
\text { (2002:108 cited Mullen,1998). }\end{array}$ \\
\hline Florence Stone & $\begin{array}{l}\text { Mentorship is a process by which a wise and helpful guide or adviser } \\
\text { uses experience to show a person how to avoid mistakes he or she } \\
\text { made earlier in his career or otherwise help advance the individual's } \\
\text { career ( } 2004 \text { cited from Steel et al 2014:7). }\end{array}$ \\
\hline Nikos Bozionelos & $\begin{array}{l}\text { Mentoring is defined as a developmental relationship that involves } \\
\text { organizational members of unequal status or, less frequently, peers } \\
\text { (2004:25 cited Kram's } 1985 \text { work). }\end{array}$ \\
\hline Barry Bozeman and Marry K. Feeney & $\begin{array}{l}\text { Mentoring is a process for the reciprocal, informal transmission of } \\
\text { knowledge, social capital, and psycho-social support perceived by the } \\
\text { recipient as relevant to work, career, or professional development; } \\
\text { mentoring entails informal communication, usually face to face and } \\
\text { over a sustained period of time, between a person who is perceived } \\
\text { to have greater relevant knowledge, wisdom, or experience (the } \\
\text { mentor), to a person who is perceived to have less (the protégé) } \\
(2008: 5) \text {. }\end{array}$ \\
\hline David Kay and Roger Hinds & $\begin{array}{l}\text { Mentoring is an approach to people development that is } \\
\text { independent of and takes place outside of any line management } \\
\text { relationship (2009:3). }\end{array}$ \\
\hline $\begin{array}{l}\text { Jamshed Memon, Zaidi Abd Rozan, } \\
\text { Mueen Uddin and Asadullah Shah }\end{array}$ & $\begin{array}{l}\text { Similarly, in modern times, the term mentor has come to denote a } \\
\text { person with certain qualities, or who is in a position of authority that } \\
\text { watch benevolently over a younger person who benefits from } \\
\text { counsel and support from the mentor. The original meaning of the } \\
\text { word mentor refers to a father figure who sponsors, guides and } \\
\text { develops a younger person (2013:733) }\end{array}$ \\
\hline
\end{tabular}

** These definitions are retrieved from articles from peer-reviewed journals that are accessible as of the date of writing. This framework is based on the work of Bozeman and Feeney (2007) and new definitions are also added.

To sum up mentoring relationship is a kind of interaction between mentor and mentee/protégé, both sides are coming with their own experiences, thoughts, knowledge, interests, different backgrounds, and different development needs etc., thus every mentorship has unique nature. Idiosyncratic interaction patterns define and shape such relationship. Mentoring is a learning partnership, because nearly all of them involve acquisition of knowledge in some sense. It is a process in which its structure could be reshaped on different phases with different needs, so mentoring relationship is dynamic and change over the period. Mentoring is mutual relationship, yet there is an asymmetry. Although mentor could benefit from giving mentorship, the focus of this relationship is to satisfy specific or general development needs of the mentee/protégé (Eby et al 2007:10).

\subsection{Entrepreneurial Mentoring: Revisiting Mentoring in Entrepreneurship Context}

Although, mentoring is rapidly gaining in popularity as a customized way to assist and support new start ventures, most of the scientific literature on the subject of mentoring concentrates on highly placed individuals providing high level of knowledge and sharing experience for those need in their career development (St Jean and Audet, 2009). This indicates an intra-organizational point of view where the mentor and mentee(protégé) work for same organization (Bishop,2012; St Jean and Audet,2009). Even it is stated long ago in 1985 by Kram's work that mentoring must be examined in a variety of contexts (St-Jean and Mathieu,2015), there are few exemptions explaining mentoring for self-employed (Weijman, Sijde and Bentham,2008). Then the attention has turned on it as a supportive mechanism for new business ventures/start-ups as well. Therefore, it is recognized that its role is changing (Sullivan,2000) in accordance with conditions in that environment, expectations from mentees(protégés), characteristics of both sides, types of relationship (e.g. formal/informal), policies and regulations adopted so on so forth. At this point, Waters et al tried to close the gap in the literature with the study focusing on the role of mentoring in new business start-ups. This effort represents the 
beginning of the focus that has shifted from existing organizations to emerging ones (Waters et al 2002; Wooten, Timmerman and Folger,1999). This is because of an understanding of non-traditional career paths for employees have emerged, life-long commitment for a job, for a company, for an owner are all becoming minor issues in working life (Waters et al 2002). Together with this differentiation working life has passed, functions and character of mentoring relationship have also changed in several ways. For example, experience was regarded as a function of vertical ranks and illustrated power in the organization, but in a new business context mentor's business and technical experience create the basis for career-related function. In some instances, mentoring relationships likely occur under formal programs which are structured for new ventures that potentially influences the opportunity to develop close relations at the beginning (Waters et al 2002). As a hybrid version of mentoring (Edwards,2016), it has been reframed in entrepreneurship context and defined as "a support relationship between an experienced entrepreneur- mentor and a novice entrepreneur (mentee- the protégé) to foster the latter's personal development." (Memon et al 2013; St Jean and Audet,2009).

Although scholarly efforts exploring mentoring in entrepreneurial sense are few in number, it is possible to find studies approaching mentoring from an entrepreneurial sense. For example, Sullivan (2000)'s study on entrepreneurial learning and mentoring emphasizes added value of mentorship for long term benefits of entrepreneurs. At the same time, as a learning mechanism entrepreneurs are assumed to learn from previous experiences of their mentors and modify their future by exemplifying critical incidents they come across along the way (Sullivan, 2000). Another study conducted by Weijman, Sijde and Benthem (2008) to reveal perceptions of mentors and mentees (protégés) under different development programs for knowledge intensive start-ups across Europe, overall mentoring process and its short/long term outcomes. This study also operationalized and discussed several variables as frequency/intensity of the contact, trust and benefits as short term outputs, depth of the relationship in the long term, career related and psychosocial support. Kaffka and Krueger (2012) are among those scholars empirically investigated the effect of intensive mentoring and feedback on co-evolution of cognitive development of entrepreneurs and their venture. They categorized entrepreneurs in three groups. Their findings indicate that entrepreneurs appreciate mentoring and panel feedback that help them to mainly in terms of reflecting on the business idea, setting up networks in order to find investors or collaborative partners for business idea development. Opportunity recognition is another area of interest in entrepreneurial mentoring research, Ozgen and Baron investigated effects of mentors, industry networks, and professional forums as social sources of information for opportunity recognition. They extended previous research findings by showing the fact that reliance on mentors can facilitate opportunity recognition by entrepreneurs, suggest that nascent entrepreneurs, like individuals in many other career paths, can benefit greatly from having a mentor. Mentor role before founding a new venture has also been discussed by St-Jean, Janssen, Baronet and Nafa (2016) who defined mentors as knowledge brokers making necessary information available to entrepreneurs and supporting emergence of new businesses in the ecosystem. Another striking example of scholarly interest in combining entrepreneurship and mentoring, St Jean and his colleagues' findings showing mentoring that increases novice entrepreneur's confidence, in turn increase the mentee's (protégé) entrepreneurial self-efficacy (St Jean and Mathieu, 2015). Furthermore, in his previous study, St Jean identified number of factors affecting the quality of mentor-mentee (protégé) relationship and level of satisfaction with this interaction (St Jean,2009). These studies are name of few exploring mentorship processes and integrating them into entrepreneurship literature. These illustrative examples indicate that, in entrepreneurial journey, mentor has an important role from the beginning with an idea towards the conceptualization and commercialization of that idea (Memon, Rozan, Uddin, Shah and Dzurllkanian, 2013). As a significant evidence of such effect, mentoring programs around the world are proliferating due to low rates of start-up survival. Hence, mentoring as an intervention tool is suggested to be an option to change inevitable end for start-ups (Memon et al 2013).

\section{Mainstream vs Entrepreneurial Perspective of Mentoring}

The first and second part of the study tries to discuss the nature of mentoring both from career development and entrepreneurship development perspective. This part deliberates overlapping and divergent characteristics of both perspectives and makes a conceptual contribution to the mentoring field. By doing this, the study also responds to the concerns in literature that mentoring should be elaborated in different contexts. Revealing significant characteristics of mentoring in both perspectives could contribute to the ever-evolving field and 
open new areas for quantitative and qualitative researches. This exploratory and conceptual study tries to show underlying features of mentoring, more deliberately compare two perspectives, and understand the evolving nature of mentoring under today's business life. Since, outstanding improvements in business life have changed the nature of static career paths and entrepreneurship has emerged as an alternative career option for individuals.

In this context, new framework has been developed for displaying changing nature of mentoring in entrepreneurial sense. Table 2. as figured below demonstrates several dimensions for both perspectives including definitions, underlying arguments, main foci, outstanding characteristics, areas for development, type and form of the relationship, relationship dynamics and functions. These mentioned dimensions have been drawn from the definitions and re-framed in accordance with main components of such definitions in the study.

Mentoring has been defined in a similar vein in both perspectives, experience for helping and development has been highlighted while explaining mentoring. On the other hand, foci have been changed from intraorganizational career perspective to inter-organizational considering self-employed. This also reflects on underlying arguments of both perspectives. From mainstream point of view, mentoring is regarded as training and development tool for upward progression on the vertical line of hierarchy. Considering entrepreneurship, there is no hierarchy even, structure of the organization has not determined yet. Therefore, asymmetry in the relationship does not come from organizational hierarchy, but also from lack of experience and knowledge in entrepreneurial mentoring. New ventures start their journey mostly with unstructured efforts, as the time passes, they start to operate business functions and formalize their ideas in a meaningful manner. Besides all these, outstanding characteristic of the relationship is the same for both understanding. Relationship is based on constructive feedbacks and guiding less experienced ones, not dictating them to show what to do and how to do. Questioning makes them to find their own ways. From a career perspective, development could be attained in educational, professional or any other sphere of life. Yet, entrepreneurial mentoring places an importance on developing entrepreneurial skills, more specifically on how to survive in business life. Lastly, mentors serve career, psycho-social and role modelling functions. Although, these functions are not in the scope of the study, possible versions of them should be explored in entrepreneurial sense. Since, there are different development needs of entrepreneurs, so the mentoring functions would be for them. They are not employees any more, they are owner and still need for development as well but specifically in different fields (see also St Jean and Audet, 2009; St-Jean,2011; St-Jean and Mathieu,2015 for entrepreneurial mentoring functions). 
Table 2: Mainstream and Entrepreneurial Perspective of Mentoring

\begin{tabular}{|c|c|c|}
\hline Perspective & $\begin{array}{l}\text { Mainstream (career) development } \\
\text { perspective }\end{array}$ & Entrepreneurial Development Perspective \\
\hline Definition & $\begin{array}{l}\text { the relationship between an older, more } \\
\text { experienced mentor and a younger, less } \\
\text { experienced protégé for the purpose of helping } \\
\text { and developing the protégé's career. }\end{array}$ & $\begin{array}{l}\text { support relationship between an experienced } \\
\text { entrepreneur- mentor and a novice entrepreneur } \\
\text { (mentee- the protégé) to foster the latter's personal } \\
\text { development. }\end{array}$ \\
\hline Focus & Intra-organizational career & $\begin{array}{l}\text { Intra-organizational career view is supplemented } \\
\text { with inter-organizational one particularly } \\
\text { considering the self-employed. }\end{array}$ \\
\hline $\begin{array}{l}\text { Underlying } \\
\text { Argument }\end{array}$ & $\begin{array}{l}\text { Training and development tool for upward } \\
\text { progression (on vertical hierarchy). } \\
\text { Including both professional and personal } \\
\text { growth. }\end{array}$ & $\begin{array}{l}\text { Entrepreneurial development tool. } \\
\text { No vertical hierarchy at all, human resources are } \\
\text { limited, relations are newly formed. }\end{array}$ \\
\hline $\begin{array}{l}\text { Outstanding } \\
\text { characteristics }\end{array}$ & Constructive, not dictating. & Constructive, not dictating. \\
\hline $\begin{array}{l}\text { Areas for } \\
\text { development }\end{array}$ & $\begin{array}{l}\text { Educational, professional, and other spheres } \\
\text { of life. }\end{array}$ & $\begin{array}{l}\text { Mainly entrepreneurial skills: "How to operate in } \\
\text { business life." }\end{array}$ \\
\hline Type & 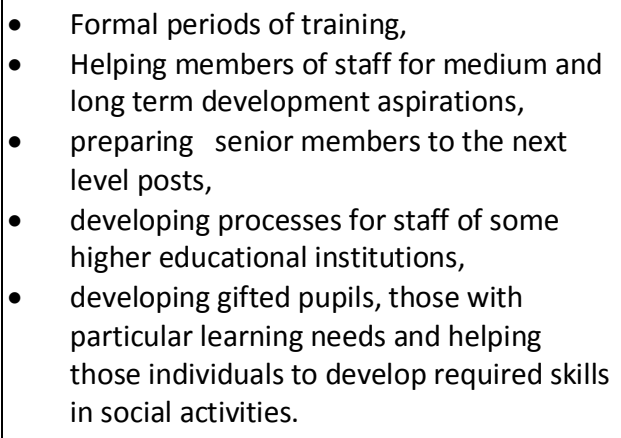 & $\begin{array}{l}\text { Both formal and informal under structured or } \\
\text { unstructured initiatives. }\end{array}$ \\
\hline $\begin{array}{l}\text { Sides of the } \\
\text { relationship }\end{array}$ & $\begin{array}{l}\text { Mentor: High ranking, influential member of } \\
\text { the organization. } \\
\text { Mentee: Less skilled and less experienced } \\
\text { member of the organization/junior -novice } \\
\text { colleagues. }\end{array}$ & $\begin{array}{l}\text { Mentor: veteran professional, mostly prior } \\
\text { entrepreneurial experience. } \\
\text { Mentee: Founder of new venture, novice or } \\
\text { nascent entrepreneur. }\end{array}$ \\
\hline $\begin{array}{l}\text { Relationship } \\
\text { dynamics }\end{array}$ & Unequal status or, less frequently, peers. & $\begin{array}{l}\text { Inequality does not come from organizational } \\
\text { hierarchy, but from experience. }\end{array}$ \\
\hline Functions & $\begin{array}{l}\text { Career enhancing, psychosocial or role } \\
\text { modelling. }\end{array}$ & $\begin{array}{l}\text { Career enhancing, psychosocial or role modelling } \\
\text { functions and others needed to be re-defined. }\end{array}$ \\
\hline
\end{tabular}




\section{CONCLUSION}

For years, both researchers and practitioners have been dealing with new ventures and their related processes due to their potential contribution to the economic growth by generating an overall dynamism with innovations, increased variety, stimulated competition to countries in general sense (Fritsch, 2008 cited in Kösters and Obschonka, 2010; Lorrain \& Laferté, 2006). It is such a phenomenon that gains and losses could not be known before business ideas realized in the economy. High uncertainty comes with those ideas without knowing the expected payoff (Scott, Shu and Lubynsky, 2015). Although there is an uncertainty and fuzzy outcomes, entrepreneurs are considered active players with their fundamental role in the development of a healthy and vibrant economy. Since, entrepreneurs and their start-ups could be both source of gross job creation by opening up new vacancies for developing business or growing more rapidly than mature/sustained businesses (Haltiwanger, Jarmin and Miranda, 2013). Despite this potential, survival rates within the first five years of new ventures are not promising. Assuming start-ups are fundamental mechanisms in the economy, the presence of them is critical and they need support (Clarysse and Yusubova, 2014). Entrepreneurial mentoring would be considered as a supporting framework for new ventures. It seems that same concerns arise from the discussions of career and entrepreneurship literatures. However, it is likely that roles and functions of mentoring mechanism gain some new meanings for entrepreneurs, because entrepreneurial needs are different from those in typical organizational context. Process is more dynamic and demanding for new ventures, there is need to be flexible and adapt swiftly to new conditions. That's why small touch but firm interventions could create new learning opportunities for entrepreneurs.

This study has operationalized firstly mentoring from a career development perspective and given some definitions regarding mentoring. As it is seen from the definitions, experience sharing is standing characteristic for mentoring relationship. As though this could create a relationship asymmetry, there is a mutual interaction between mentor and mentee/ protégé. It is worth to mention that such relationship could contribute both sides, what possible contributions would be, what kind of latent and expressed needs of both sides, which of them is satisfied, what are the motivations behind receiving and giving mentorship are all research questions waiting to be answered. Furthermore, revealing mentoring functions and roles in entrepreneurial sense would be a promising research avenue with its practical implications. Pairing mentor(s) and entrepreneurial mentee(s) and exploring their relationship dynamics is another topic for further research.

\section{REFERENCES}

Allen, T. D., \& Poteet, M. L. 1999, “Developing effective mentoring relationships: Strategies from the mentor's viewpoint”, The Career Development Quarterly, vol. 48, no.1, pp.59-73.

Armstrong, S. J., Allinson, C. W., \& Hayes, J. 2002, "Formal mentoring systems: An examination of the effects of mentor/protégé cognitive styles on the mentoring process", Journal of Management studies, vol.39, no. 8, pp.1111-1137.

Bozionelos, N. 2004. "Mentoring provided: Relation to mentor's career success, personality, and mentoring received", Journal of Vocational Behavior, vol. 64 , no. 1, pp. 24-46.

Bozeman, B., \& Feeney, M. K. 2008, “Mentor matching: A" goodness of fit" model”, Administration \& Society. vol.40, no.5, pp. 465-482.

Bruneel, J., Ratinho, T., Clarysse, B., \& Groen, A. 2012, "The Evolution of Business Incubators: Comparing demand and supply of business incubation services across different incubator generations", Technovation, vol.32, no.2, pp.110-121.

Clarysse, B., \& Yusubova, A. 2014, "Success factors of business accelerators". Technology Business Incubation Mechanisms and Sustainable Regional Development, Proceedings, pp.1-19.

Eby, L. T. 1997, “Alternative forms of mentoring in changing organizational environments: A conceptual extension of the mentoring literature", Journal of vocational behavior, vol. 51, no. 1, pp. 125-144.

Eby, L. T., Rhodes, J. E., \& Allen, T. D. 2007, "Definition and evolution of mentoring", The Blackwell handbook of mentoring: A multiple perspectives approach, pp. 7-20.

Edwards, R. L. 2016, "The value of the business coach: Exploratory analysis of the relationship between entrepreneurial mentoring and perceptions of entrepreneurial readiness", unpublished doctoral dissertation at Webster University. 
Eesley, C. E., \& Wang, Y. 2014, "The Effects of Mentoring in Entrepreneurial Career Choice", Available at SSRN.

Ensher, E. A., Grant-Vallone, E. J., \& Marelich, W. D. 2002, “Effects of perceived attitudinal and demographic similarity on protégés' support and satisfaction gained from their mentoring relationships", Journal of Applied Social Psychology, vol. 3, no.7, pp. 1407-1430.

Fagenson, E. A. 1989, "The mentor advantage: perceived career/job experiences of protégés versus non-protégés", Journal of organizational behavior, vol.10, no. 4, pp. 309-320.

Haltiwanger, J., Jarmin, R. S., \& Miranda, J. 2013, "Who creates jobs? Small versus large versus young", Review of Economics and Statistics, vol. 95, no. 2, pp. 347-361.

Hunt, D. M., \& Michael, C. 1983, “Mentorship: A career training and development tool”, Academy of management Review, vol.8, no.3, pp. $475-485$.

Johnson, W. B. 2002, "The intentional mentor: Strategies and guidelines for the practice of mentoring", Professional psychology: Research and practice, vol. 33, no.1, pp. 88-96.

Kaffka, G. A., \& Krueger, N. F. 2012, "From Grand Idea to Viable Execution: How Do Ventures and Entrepreneurs Co-Evolve?", Available at SSRN.

Kay, D., \& Hinds, R. 2005, “A practical guide to mentoring”. England: Oxford, How to Books.

Kösters, S. \& Obschonka, M. 2010, "Building winners? An empirical evaluation of public business assistance in the founding process", Jena economic research papers, No. 2010, 025.

Kram, K. E., \& Isabella, L. A. 1985, "Mentoring alternatives: The role of peer relationships in career development", Academy of management Journal, vol. 28, no. 1, pp. 110-132.

Lefebvre, M. R., Redien-Collot, R., \& O'Shea, N. 2011, “The impact of entrepreneurial mentoring on wisdom acquisition and transmission: a dialogical and relational phenomenon", EGOS paper, pp.1-38

Lorrain, J., \& Laferté, S. 2006, "Support Needs of the Young Entrepreneur", Journal of Small Business \& Entrepreneurship, vol. 19, no.1, pp. 37-48. https://doi.org/10.1080/08276331.2006.10593357.

McManus, S. E., \& Russell, J. E. 1997, "New directions for mentoring research: An examination of related constructs", Journal of Vocational Behavior, vol 51, no.1, pp. 145-161.

Memon, J., Abd Rozan, Z., Uddin, M., \& Shah, A. 2013, "Selecting a mentor: Guide for a protégé", World Applied Sciences Journal, vol.24, no.6, pp. $732-738$.

Mullen, E. J. 1994, "Framing the mentoring relationship as an information Exchange", Human Resource Management Review, vol. 4, no. 3, pp. 257-281.

Murray, M. 2001, "Beyond the myths and magic of mentoring: How to facilitate an effective mentoring process". San Francisco: JosseyBass.

Noe, R. A. 1988, "An investigation of the determinants of successful assigned mentoring relationships", Personnel psychology, vol 41, no.3, pp. 457-479.

Ozgen, E., \& Baron, R. A. 2007, "Social sources of information in opportunity recognition: Effects of mentors, industry networks, and professional forums", Journal of business venturing, vol. 22, no.2, pp. 174-192.

Ragins, B. R., \& Cotton, J. L. 1993, “Gender and willingness to mentor in organizations”, Journal of Management, vol. 19, no. 1, pp. 97-111.

Ragins, B. R., \& Kram, K. E. 2007, “The handbook of mentoring at work: Theory, research, and practice”. Sage Publications.

Scandura, T. A., \& Schriesheim, C. A. 1994, "Leader-member exchange and supervisor career mentoring as complementary constructs in leadership research", Academy of management Journal, vol 37, no.6, pp.1588-1602.

Scott, E. L., Shu, P., \& Lubynsky, R. 2015, "Are'Better'Ideas More Likely to Succeed? An Empirical Analysis of Startup Evaluation” . Harvard Business School Technology \& Operations Mgt. Unit Working Paper, (16-013).

Singh, V., Bains, D., \& Vinnicombe, S. 2002, “Informal mentoring as an organisational resource”, Long Range Planning, vol. 35, no. 4, pp. 389-405.

St-Jean, E., \& Audet, J. 2009, "Factors leading to satisfaction in a mentoring scheme for novice entrepreneurs", International journal of evidence based coaching and mentoring, vol.7, no. 1, pp. 148-161.

St-Jean, É., \& Mathieu, C. 2015, "Developing Attitudes Toward an Entrepreneurial Career Through Mentoring The Mediating Role of Entrepreneurial Self-Efficacy", Journal of Career Development, vol. 42, no. 4, pp. 325-338.

St-Jean, É., Tremblay, M., Janssen, F., Baronet, J., Loué, C., \& Nafa, A. 2016, “May business mentors act as opportunity brokers and enablers among university students?", International Entrepreneurship and Management Journal, pp. 1-15.

Stone, F. 2004, "The mentoring advantage: Creating the next generation of leaders". Dearborn Trade Publishing . 
Sullivan, R. 2000, "Entrepreneurial learning and mentoring", International Journal of Entrepreneurial Behavior \& Research, vol. 6, no.3, pp.160-175.

Tepper, B. J. 1995, "Upward maintenance tactics in supervisory mentoring and nonmentoring relationships", Academy of Management journal, vol. 38, no.4, pp.1191-1205.

Turban, D. B., \& Dougherty, T. W. 1994, "Role of protégé personality in receipt of mentoring and career success", Academy of Management journal,vo.l 37, no.3, pp. 688-702.

Wanberg, Connie R, Welsh, Elizabeth T, Hezlett, Sarah A. 2003, "Mentoring Research: A review and dynamic process model", Personnel and Human Resources Management, pp.39-124.

Waters, L., McCabe, M., Kiellerup, D., \& Kiellerup, S. 2002, "The role of formal mentoring on business success and self-esteem in participants of a new business start-up program", Journal of business and psychology, vol. 17, no. 1, pp. 107-121.

Weijman, G., Sijde, P., \& Benthem, J. 2008, "Harvesting the results of the mentoring process of knowledge intensive startups", Working Paper, pp.1-16.

Whitely, W. T., \& Coetsier, P. 1993, "The relationship of career mentoring to early career outcomes", Organization Studies, vol 14, no.3, pp. 419-441.

Wooten, K. C., Timmerman, T. A., \& Folger, R. 1999, "The use of personality and the five-factor model to predict new business ventures: From outplacement to start-up", Journal of Vocational Behavior, vol. 54, no. 1, pp. 82-101.

Young, A. M., \& Perrewé, P. L. 2000, "The exchange relationship between mentors and protégés: The development of a framework", Human Resource Management Review, vol.10, no.2, pp.177-209.

Authors' Note: This study is based on unpublished dissertation of Seray Begum Samur-Teraman supervised by Associated Professor Hande Sinem Ergun. 